\title{
A REVIEW OF THE NATIONAL ENERGY BOARD POLICIES AND PRACTICES AND RECENT HEARINGS
}

\author{
R. J. GIBBS, D. W. MacFARLANE, and H. J. KNOWLES*
}

Under the National Energy Board Act and Regulations thereunder, a purchaser who intends to export natural gas from Canada must obtain an export licence from the National Energy Board. In the fall of 1969, the National Energy Board had before it several applications for licences to export natural gas in a total amount which was quite large in relation to the previously licenced exports. In addition to combining the applications for export licences, the Board decided that the combined hearing would be an opportune occassion for it to reconsider the criteria and practices which it had used in the past to deal with applications for gas export licences, and as such, the Board invited the applicants, six of the provinces and three industry associations, to present evidence and argument with respect to general policy matters to be followed by the Board. This article is a study of the said hearing and consists of an outline of the legislative background to the $\mathrm{Na}$ tional Energy Board Act, a review of the past policies of the Board, a description of the practices and procedures of the Board, a commentary on several of the submissions made to the Board and a summary of the positions taken by the various parties and intervenors.

\section{A. INTRODUCTION}

At 1.00 p.m. on March 20th, 1970, the National Energy Board completed what is believed to have been the longest consecutive hearing that any oil and gas regulatory agency has presided over in Canada since World War II.** The hearing commenced on November 25th, 1969. The sessions were held from 9.00 a.m. to 1.00 p.m. each weekday for a total of 54 hearing days including argument. As well, there were three adjournment breaks, one over Christmas, one at the beginning of February and one in March just before argument commenced on March 17th.

The original purpose of the hearing was to consider five applications for licences to export gas and to consider applications from some of the export applicants or their subsidiaries for certificates of public convenience and necessity authorizing the construction of pipeline facilities. If the hearing had been restricted to its original purpose, it would probably have been completed in three or four weeks. However, the National Energy Board elected to hear representations on six policy matters at the same time and, in effect, to have a combined substantive and policy hearing.

The policy matters were set out in the following letter from the Board's secretary:

The Board now has before it a number of applications for licences to export natural gas. The quantities of gas involved are, in aggregate, very substantial. The supplydemand relationship respecting natural gas in North America is undergoing significant changes, the implications of which are by no means clearly established. In the decade of the Board's experience, it has developed certain criteria and methods

- This paper was prepared through the combined efforts of R. J. Gibbs, McLaws \& Company, Calgary; D. W. MacFarlane, Law Department, Mobil Oil Canada, Ltd. Calgary; H. J. Knowles, Wahn, Mayer, Smith. Creber, Lyons, Torrance \& Stevenson, Toronto; F. W. Kelly, Law Department, Imperial Oil Limited, Calgary; C. R. Fetherston, Law Department, Shell Canada Limited, Calgary; L. B. Bannicke, Law Department, Hudson's Bay Oil and Gas Company Limited, Calgary, and delivered by Messrs. Gibbs, MacFarlane and Knowles at the 9th Annual Research Seminar of the Canadian Petroleum Law Foundation. The authors acknowledge as a reference source, and have in some instances incorporated, material extracted from summaries of the hearings as published in Fosters Natural Gas Reports, Foster Economic Consultants, Ltd., Calgary.

* Editor's Note: Since the presentation of this paper at the Ninth Annual Research Seminar in Oil and Gas Law, the National Energy Board, in August, 1970, handed down its decision in the said hearing. 
of evaluation for such matters as Canadian requirements, reserves, surplus, prices for gas to be exported and duration of licences. These criteria and methods may or may not continue to be appropriate in the assessment of applications now before the Board, or to come before it in the future.

It is the desire of the Board to obtain and use the knowledge and wisdom of those engaged in or affected by the natural gas industry in re-assessing the criteria and methods which the Board may best apply in deciding upon the applications for licences to export natural gas now before it.

Accordingly, aside from such deficiency letters as may be addressed to applicants concerning matters peculiar to their respective applications, the Board invites each applicant to adduce such evidence and argument as may in the view of the applicant be relevant to the public interest, in respect of general matters including the following:

1. Methods and assumptions appropriate to the determination of:

(a) reasonably foreseeable requirements for natural gas for use in Canada;

(b) gas reserves in Canada;

(c) surplus remaining after due allowance has been made for the reasonably forseeable requirements for use in Canada having regard to the trends in the discovery of gas in Canada;

(d) the justness and reasonableness in relation to the public interest of the price to be charged by an applicant for gas exported by him;

(e) the order of priority to be given various classes and kinds of proposed export in the event that the surplus remaining at a given time is less than the sum of the quantities of gas for which licences are sought at that time.

2. The feasibility of protecting the public interest in respect of the price to be charged for gas exported, having regard for changing price levels from time to time, by instituting procedures such as:

(a) the restriction of the duration of licences to periods substantially shorter than the 25-year maximum authorized by the Act;

(b) price escalation at fixed periods;

(c) price determination at stated intervals in relation to specified indices.

3. Such other matters as may seem relevant to the proper discharge of the duties of the Board in respect of applications for licences to export natural gas, and to the public interest.

While this invitation may, at the option of the applicant, be responded to in evidence and argument upon the hearing of the application, it would assist the Board and other interested persons if any views which the applicant wished to put forward were made available to the Board and to interested persons prior to the hearing of the application.

It is the intention of the Board to hear sequentially all the applications now on file for licences to export natural gas commencing as soon as practicable, probably in the first week in November, and at such hearing to consolidate those aspects of the various applications having to do with Canadian requirements, reserves, deliverability, trends in discovery, and surplus, and thereafter to hear those aspects of each application not included in the foregoing. The order in which the Board will hear applicants, and other aspects of the combined and sequential hearings, will be established at a prehearing conference. The date of such prehearing conference will be the subject of discussion with counsel.

Unless good reason for otherwise deciding should appear, it is the intention of the Board that the prehearing conference and the hearing or hearings be held in Ottawa.

This letter is being addressed to the following:

The Secretary,

Alberta \& Southern Gas Co. Ltd.;

Mr. Keith E. Eaton

for Canadian-Montana Pipe Line Company;

Mr. G. Douglas Nichols

for Consolidated Natural Gas Limited;

Mr. R. G. Graham, President,

Inter-City Gas Limited; 
Mr. J. M. Cameron,

Trans-Canada Pipe Lines Limited;

Mr. C.D. Williams, Q.C.

Westcoast Transmission Company Limited.

A copy of this letter has also been sent to the Attorney's General of the Provinces of British Columbia, Alberta, Saskatchewan, Manitoba, Ontario and Quebec and to the Canadian Petroleum Association and the Canadian Gas Association and the Independent Petroleum Association of Canada.

The number and identity of the parties who were represented at and who took an active part in the hearing is indicative of the widespread interest or concern or apprehension raised by the policy matters listed in the letter, particularly, when superimposed upon the applications which were also before the Board. Upwards of forty parties participated in some degree either by way of leading evidence or by cross-examination of witnesses led by other parties or both. There were the five applicants, six provincial governments, two producing industry associations, and the remainder were oil and gas exploration companies and utility companies. In addition, there were written submissions, not supported or adopted by witnesses, from other entities such as civic governments, large industrial consumers, and from at least one union.

The interventions, as distinct from the applications, were, with some exceptions, generally responsive to the policy matters raised in the Board's letter. As might have been expected the interests of different sectors of industry and the regional interests based upon geographic location resulted in a wide range of views and recommendations. The Board proved to be willing to hear all submissions even to the point of entertaining a new one which was introduced during the course of the hearing and which was not responsive to the policy letter. Evidently, the Board was of the opinion that it could listen to and give cognizance to any view relative to any aspect of the natural gas business under the advisory powers contained in Section 22(1) of the National Energy Board Act: ${ }^{1}$

22(1) The Board shall study and keep under review matters over which the Parliament of Canada has jurisdiction relating to the exploration for, production, recovery, manufacture, processing, transmission, transportation, distribution, sale, purchase, exchange and disposal of energy and sources of energy within and outside of Canada, shall report thereon from time to time to the Minister and shall recommend to the Minister such measures within the jurisdiction of the Parliament of Canada as it considers necessary or advisable in the public interest for the control, supervision, conservation, use, marketing and development of energy and sources of energy.

The wide divergence of interests brought out conflicting suggestions, views which were diametrically opposed and recommendations which were irreconcilable to the point where what had been intended as a policy hearing developed into an adversary proceeding. When it became clear that the hearing had become one of an adversary nature, the sequence of leading evidence and conducting cross examination became of prime importance.

At the commencement of the hearing the Board advised the applicants and intervenors that each of the topics in its policy letter would be dealt with in the order set forth in the letter and that the remaining substantive matters of the actual applications would then be heard.

' S.C. 1959 , c. 46 , as amended. 
The order of precedence which was established was applicants in alphabetical order, provincial governments in alphabetical order, associations in alphabetical order, and lastly, other intervenors (exploration companies, distribution companies and so on) in alphabetical order. Every witness was subject to cross-examination by the parties in the order of precedence, plus, after cross-examination had been completed by the "other intervenors", the Board's counsel and the Board members.

Basic to an understanding of the hearing is the realization that various applicants were in contest with each other, the most marked example being the adamant opposition of Trans-Canada Pipe Lines to the application of Consolidated Natural Gas Limited. It should not be thought, however, that these were the only two to be in conflict. Although it was not always evident on the surface, there were underlying cross currents involving all of the applicants. This also applied to a good many of the intervenors including the provincial governments.

It is not therefore surprising, that what became known as "benign questioning" made itself evident quite early in the hearings. This was a method whereby an intervenor well down the alphabetical list, by arrangement or because his sympathies were with one particular applicant, could bring out, on cross-examination of a witness, evidence which was unfavourable to other applicants or prior intervenors, after the parties prior to him in the order of precedence had had their turn at cross-examination and were thus powerless to test the witness on the favourable, and sometimes new, evidence. Ultimately, this led to an application to change the order of precedence. The application was granted with the result that, part way through the hearing, the applicants, still in their alphabetical sequence, were shifted to the bottom of the order of precedence. This is but one example of the procedural problems which developed due, in part, to combining a policy hearing with a substantive hearing.

Although the procedural aspects of Board practice arouse some concern and may require careful study before another large hearing is scheduled, there are other matters of far more moment. The scope of the hearing and the number and the variety of topics debated during the course thereof leave little doubt that the decision of the Board and the policies it might adopt as a result of representations made to it could have far reaching implications. Ground rules may be developed and employed as guide lines for those involved in the natural gas industry for perhaps ten years or more. In this context, responsible people in the industry and those connected with the industry began to ask themselves searching questions. Who is the Board? What are its powers? What are its limitations? Where did it originate? What tests does it use? How does it function? What pressures is it subject to? What is the public interest? Who is the public? It seemed to be a time to review the past to determine how we reached the present position, and a time to try to forecast what the future holds. It is to that objective that this paper is directed.

\section{B. LEGISLATIVE AND ADMINISTRATIVE BACKGROUND}

A full appreciation of the political and legal implications of existing legislation relative to the control of gas exports from Canada can 
only be gained by a consideration of prior legislative enactments, the jurisprudence resulting therefrom in the form of administrative and quasi-judicial decisions, the public and political reaction to those decisions, and finally, the apparent reasons for subequent amendments to the statute.

Control over the export of gas was initially exercised pursuant to regulations ${ }^{2}$ under the Exploration of Power and Fluids and Importation of Gas Act. ${ }^{3}$ After providing that the Minister must be satisfied that the gas "is surplus after due allowance has been made for distribution to customers for use in Canada", the relevant regulation as to price provided as follows: ${ }^{4}$

The price charged by a licensee for power or gas exported by him shall not be lower than the price at which power or gas, respectively, is supplied by him or his supplier in similar quantities and under similar conditions of sale for consumption in Canada.

What came to be the most controversial export application under the aforesaid Regulation 9 was made by Westcoast Transmission Company Limited in June of $1955 .^{5}$ It was the first proposal for large scale long distance transmission of Canadian gas to a foreign market. Underlying the application was an agreement between Westcoast and Pacific Northwest Pipeline Corporation, a U.S. purchaser, for the sale of gas at a price of $221 / 4 \mathbb{4}$ per mcf until January 1st, 1959, and 224 per mcf for the balance of the term of the contract. The price to be paid by Pacific Northwest caused considerable comment in the press and in Parliament because of the higher rate charged by Westcoast for gas delivered to the domestic distributing companies in British Columbia, namely to B.C. Electric and to Inland Natural Gas, which was 324 per mef at $90 \%$ load factor. In defence of the price to Pacific Northwest, Westcoast contended that the gas delivered to the export market was not being supplied in similar quantities nor under similar conditions to that being supplied for consumption in Canada. Westcoast pointed out in its submission to the Borden Commission on Energy ${ }^{6}$ that the Pacific Northwest contract provided for the sale of 300,000 mcf per day at a $90 \%$ load factor for which Pacific Northwest was required to pay whether taken or not. The B.C. Electric contract, on the other hand, did not require that B.C. Electric take any particular volume of gas and they were not required to pay for any gas not taken. Furthermore, the B.C. Electric contract was originally negotiated on the then estimate that B.C. Electric would require about $40,000 \mathrm{mcf}$ per day at the end of a five year period, which amounted to only approximately $13 \%$ of the contract obligation of Pacific Northwest. Westcoast also contended that the sale of gas to B.C. Electric was at the point of consumption, whereas the sale of gas to Pacific Northwest was at the international border where there were no customers, the major point of consumption being far to the south. Westcoast's submission went on to say:

No community in the Pacific Northwest States is receiving natural gas at a lower city gate rate than Vancouver. The City rates at the boundaries of Seattle, Port-

isegulations respecting the Exportation of Power and Fluids and the Importation of Gas, Order in Council P.C. $1955-907$.

${ }^{3}$ S.C. 1955, c. 14.

- Supra, n. 2, Regulation 9.

s See the First Report of the Royal Commission on Energy, October, 1958, 13-24.

- The Royal Commission on Energy, Henry Barden, Q.C., Chairman, appointed by Order in Council P.C. 1957-1386. 
land and other areas in the Pacific Northwest States were originally the same as for the Vancouver area. However, Pacific Northwest has made application to the Federal Power Commission for, and has put into effect, an increase in rates of $17 \%$ which has increased the city gate rates payable by the United States communities from 32屯 to 37.44. Pacific Northwest is free to apply for further increases as its costs increase from year to year.

Without the sale of $300,000 \mathrm{cu}$. ft. per day by Westcoast at the border, Westcoast could not have built a pipeline from the Peace River area to deliver gas at Vancouver under a rate of about $\$ 2.00$ per mcf.

If the Peace River gas were not available for Vancouver from the present Westcoast system, Vancouver's only recourse would have been to obtain gas from the Pacific Northwest Company at the same rate it is now paying Westcoast plus the $17 \%$ increase now in effect, plus any additional increase which Pacific Northwest Company would charge in the future, plus the import duty on gas currently fixed at $3 \leftarrow$ per mcf.

The facts are that Westcoast negotiated the best possible price at the border in 1954 based on fuel oil competition and the competition of supplies of gas from United States sources. Westcoast adopted the city gate rate of competitive United States gas at Vancouver which initially was based on fuel oil competition at Portland, despite the fact that all costs of fuels in Vancouver were much higher than in Portland at the time the rates were fixed. B.C. Electric, after full investigation, entered into its 20 year contract in order to ensure a firm supply for all its requirements for twenty years from Westcoast.

The negotiating of the $22 \uparrow$ price at the border by Westcoast was fully publicized in December, 1954, again fully disclosed before the Oil and Gas Conservation Board of Alberta in March, 1955, again fully discussed before the Board of Transport Commissioners in June, 1955, and full information furnished to the Department of Trade and Commerce on the application for the export licence. As a result of the contract fixing the $22 \mathrm{c}$ price on the sale of 300,000 mof per day, Westcoast has supplied gas to communities in British Columbia at a price much less than could be obtained otherwise, and it has completed its project without any subsidy or cost to the people of Canada with benefit to thousands of residents in British Columbia and has provided British Columbia and northern Alberta with a natural gas industry.

Notwithstanding the arguments made by Westcoast before the Borden Commission to justify the decision of the Board of Transport Commissioners, the Commission did not consider the regulation under which the approval had been given was effective in achieving the objective it was designed to accomplish. After reprinting the regulation, the Commission wrote: ${ }^{7}$

While the Commission believes it understands the result which Regulation 9 was designed to accomplish, nevertheless we have found it most difficult and, indeed, almost impossible to interpret. In the first place, the quantities and conditions of natural gas sales vary greatly as between contracts, so that price comparisons are difficult to make. The usual method of determining appropriate prices is based on a computation of cost of service and there are various methods of allocating certain of these costs to different types and quantities of sale. Furthermore, the regulation does not take into account other factors, such as competitive prices and value of service, factors which many authorities believe should be taken into account in the setting of prices. In the opinion of the Commission, Regulation 9 should be rescinded.

The Commission believes that, if a National Energy Board enquires into the terms and conditions of each proposed export contract, satisfies itself that the terms are fair and reasonable and in the public interest, and discharges the other responsibilities which the Commission is recommending should be placed upon it, the objectives which the Commission assumes were envisaged by Regulation 9 will be achieved.

It is interesting to note that when what is now Section 83 of the National Energy Board Act was being debated in the House, the

Supra, n. 5 at 13. 
Liberal opposition, supported by the C.C.F., attempted to re-introduce by way of amendment the substance of Regulation 9, notwithstanding the Borden recommendation referred to above. Mr. Churchill, Minister of Trade and Commerce, in the course of the debate stated:

My honourable friends, now faced with that [the Borden recommendation] are attempting to have it re-established in the legislation. That regulation is precisely the one which gave rise to the difficulties out at the west coast because of the phrase 'in similar quantities and under similar conditions of sale', and it is very difficult to get the two situations exactly similar. For that reason, along with other things that we have done in the legislation, we have left it to the Board to determine what is just and reasonable in the circumstances; is it just and reasonable with regard to the price to be charged by an applicant for gas or power exported by him and is it just and reasonable in relation to the public interest. The Board we think will have to take into account the very factors my honourable friends are pointing out as to whether the public interest is protected, and to make sure that Canadians are not placed at a disadvantage with regard to their competitors in the United States. Our experience in Canada dates back to the days long before gas was used in this country when hydro-electric power was being developed in this country some of it was done by United States capital. The power was exported across the line and used to build up United States industry there. Many years ago our people discovered that the advantage lay with the United States using the power that was developed in Canada. With that experience behind us we do not want to have the same thing happen with regard to this other great source of energy, namely natural gas.

Surely this is something that the energy board will take into account when it is considering the applications for export. At the same time I am sure they will have to take into consideration the cost to Canadian consumers if there is no export of gas. A line built at tremendous expense might operate at only a fraction of its total efficiency unless some gas was exported. If it operates lower than its full efficiency, obviously the price to the Canadian consumer will rise. The Board will have to weigh and balance these factors one against the other and see what is to the advantage of Canada. With difficulties that have already arisen and are apparent to Canadians under Regulation No. 9 which I have just read we thought the wise thing to do was to give the Board freedom of action to weigh all those factors and determine what was just and reasonable in relation to the public in. terest and that is why the clause is worded as it is.

The debate went on with the Liberal opposition continuing to press for amendment to include the substance of former Regulation 9. Mr. Churchill made the further statement:

It is because Regulation 9 did not give the protection that everybody wants, and the whole House of Commons is in agreement with this, that the Borden Commission rejected Regulation 9 and suggested another way of dealing with it. Our drafting of the Bill is made to achieve exactly that desired end. We put it up to the Energy Board to size up all the factors concerning each contract for export and determine, as it says here, that the price to be charged by an applicant for gas or power exported by him is just and reasonable in relation to the public interest. The public interest means the Canadian public interest and surely the public interest means the development of Canadian industry. This does not mean to make it possible for a competitor across the line to gain an advantage from the use of our natural resource, gas.

That is what the Prime Minister had in mind, that the public interest would be protected by giving this type of authority to the Energy Board who would not be cribbed, cabined and confined by Regulation 9 which is a restrictive regulation. Here the Board can take account of all the factors which should be considered and there is no doubt in my mind after the Borden report and after the lengthy discussion here in the House of Commons but that the Energy Board to be set up will take fully into account the Canadian national interest and take fully into account the expressions of opinion here from both sides of the committee leading towards the same objective.

In the result, Section 83 of the National Energy Board Act was enacted. It provides as follows: 
Upon an application for a licence the Board shall have regard to all considerations that appear to it to be relevant and, without limiting the generality of the foregoing, the Board shall satisfy itself that:

(a) the quantity of gas or power to be exported does not exceed the surplus remaining after due allowance has been made for the reasonably foreseeable requirements for use in Canada having regard to the trends in the discovery of gas in Canada; and

(b) the price to be charged by an applicant for gas or power exported by him is just and reasonable in relation to the public interest.

In retrospect and particularly in the light of the evident concern of Canadian utility companies that rising export prices may exert upward pressure on domestic prices, it is interesting to note that the paramount concern of federal legislators in passing subsection (b) of Section 83 was to plug the loophole in Regulation 9 which had allowed gas to be exported to the United States at prices lower than those being charged to Canadian consumers in British Columbia. It seems clear from the record of parliamentary and committee debate that at no time did the participants in the debate consider that it could conceivably be contrary to the public interest for gas to be sold in the export market at prices higher than those then being charged in Canada. Yet, as we will later observe, it is in this area that the domestic utilities and others now argue that the Canadian "public interest" is being adversely affected by export of Canadian gas.

\section{PAST POLICIES OF THE BOARD}

In 1967 the National Energy Board faced the task of applying Section 83 to an application by Westcoast for approval of additional exports to Pacific Northwest. Although the question of whether a surplus actually existed presented no particular problem, it was found not be be a simple matter to apply Section 83(b). In 1960 Westcoast had undertaken by letter to the Minister of Trade and Commerce to limit its exports under its earlier licence and

to insure that the aggregate of natural gas to be exported by Westcoast will be sold at prices which, when averaged, are fair and reasonable, after taking into account the price (22c U.S. per mcf) at which natural gas is being sold to Pacific Northwest under its contract with Westcoast dated December 11th, 1954.

In 1966 Westcoast entered into an agreement with El Paso Natural Gas (at that time the successor to Pacific Northwest) for additional sales which were approved (as being consistent with the above commitment and resulting in an export price which was just and reasonable in relation to the public interest of Canada) by the National Energy Board which issued a licence accordingly. However, the Federal Power Commission found that the agreement was not consistent with the public interest of the United States. Westcoast and its purchaser quickly entered into an amending agreement intending thereby to conform with the stipulations of the Federal Power Commission and applied to the National Energy Board for approval of exports based on the revised agreement. In determining whether the new price was just and reasonable in relation to the Canadian public interest, the Board stated that it applied three tests:

(1) Does it recover its appropriate share of the costs incurred by the Canadian transmission company?

(2) Is it not less than the price to Canadian consumers of the transmission company in the general area of the proposed export, after allowance for variations in the terms of delivery? 
(3) Does it result in prices in the United States market area close to the least cost alternative for energy from indigenous sources?

The Board concluded that the first two tests had been satisfactorily met, but that based upon its own studies, the proposed export price did not satisfy the third test, because it was low in relation to the value of gas from other sources in the market area by a difference of some $4 \frac{1}{2} \mathbb{C}$ per mcf which was described as "material", being some $14 \%$ of the proposed export price. The Board stated that:

If the bargain were one freely arrived at by two equal parties as a result of arm's length negotiation, the Board would be hesitant to assert that the price did not represent a fair assumption of the value of the gas from the viewpoint of each of the parties. This is not here the case. The terms of the Amendatory Agreement are advised to meet the language of ordering paragraph $B$ of Opinion 526.

The Board found that although the Amending Agreement met the price requirements of the Federal Power Commission it was not acceptable to Canadian authorities because it did not meet all three tests.

A confrontation between the National Energy Board and the Federal Power Commission resulted, with the matter being ultimately resolved through meetings between the two, followed by approval of a settlement offer at compromise border prices. In its final decision, the National Energy Board concluded that "in the circumstances of this case this price bears a reasonable relationship to the least cost alternative for the Pacific Northwest for energy from indigenous sources," and went on to observe that any remaining doubts it might have about the border price "should be overweighed by general considerations of the public interest in a constructive end to a difficult matter."

Another aspect of the confrontation resulted from a suggestion in Federal Power Commision Opinion 526 to the effect that gas from Alberta \& Southern Gas Co. Ltd., (then the subject of a pending application before the Federal Power Commission) might be diverted to the market proposed to be served by El Paso with Westcoast's gas, with a resulting lower cost in the market area. Commenting on this, the National Energy Board stated that

this Board is constrained to observe that a major permanent diversion of gas of Canadian origin from the market contemplated at the time of approval of export would deprive this Board of any means of assuring itself that the price for gas to be exported was reasonable in relation to its value in the market area, and would consequently require a radical re-assessment of Canadian gas export policy.

As a result of all this, moves were soon made to provide for greater co-ordination between the Federal Power Commission and the $\mathrm{Na}$ tional Energy Board on an informal basis to avoid the embarrassment of future confrontations which are regarded as highly undesirable by authorities on both sides of the border. About this time there was created in the United States an Energy Policy Staff in the Presidential Office of Science and Technology, and its director indicated that a function of this group would be to act as a catalyst in resolving policy matters before they become major internal problems, and it seemed that the Energy Policy Staff might play an important role as an intermediary between the Federal Power Commission and the National Energy Board in future import/export proceedings. It is not known to what extent this has been operative, but informal meet- 
ings have been held between the membership of the two agencies on a number of occasions.

In dealing with Item 1(d) and Item 2 of the Board's September 10th, 1970, letter, the implications of Board policies as to export price will be further considered.

\section{REQUIREMENTS, RESERVES AND SURPLUS}

\section{Background}

It is difficult to consider Board procedures and policies with respect to the determination of either Canadian requirements or available gas reserves without having an appreciation of the manner in which these factors are taken into account in the calculation of surplus. As noted earlier, Section 83(a) of the National Energy Board Act provides that the quantity of gas to be exported is not to exceed the surplus remaining "after due allowance has been made for the reasonably foreseeable requirements for use in Canada having regard to the trends in the discovery of gas in Canada."

In its August, 1966, report on the application of Trans-Canada Pipe Lines Ltd. (Great Lakes), the National Energy Board, having re-examined the method which it had used in its earlier reports, stated that the following principles would be applied in determining current surplus:

(a) Available reserves will include the remaining volumes under existing import Licences, plus contractable reserves. The Board considers contractable reserves to be those established reserves which it believes a purchaser will be able to contract for, with delivery to begin within the next four years.

(b) Protection of Canadian gas requirements at an adequate level will be achieved if an amount of reserves equal to 25 times the estimated requirement level for the fourth year is set aside. The multiplier of 25 was selected not only because it appears to the Board to supply adequate protection under presently foreseeable circumstances, but also because it corresponds with the 25-year maximum term for export Licences which can be granted by the Board. The fourth-year level was selected because it corresponds with the current policy of the pipeline companies in contracting for the purchase and sale of gas. These contracts provide for a time interval of not more than four years before acceptance and delivery of gas to meet forward requirements.

In cases where authorization for removal of gas from the province in which it is produced is required by a statute of that province, the amount of protection provided for markets in the province will be the amount set by the province to be its requirement or the amount computed by the above rule, whichever is greater.

(c) Canadian market requirements, existing export Licences, and those for which applications are under consideration, will not be given terminal year peak-day protection from established reserves provided that a surplus is indicated by calculating the difference between

(1) the established reserves plus those indicated by the trends in the growth of reserves, and

(2) the forecast Canadian requirements over a 30 -year period, including terminal year peak-day protection plus export commitments

and further provided that in the opinion of the Board, the trend in the growth of reserves justifies continued confidence.

Applying these principles in its March, 1967, report on the application of Westcoast, the Board estimated that the established reserves of Canada as of June 30th, 1966, were 47,997 bcf located as follows:

Alberta 40,037

British Columbia

6,750

Saskatchewan 930

Northwest Territories .................... 100

Other 180 
It also concluded that as of that date 6,665 bcf were not available to meet current market requirements because they were beyond economic reach or deferred for reasons of conservation, and that the situation as at June 30th, 1966, could be summarized as follows:

Canadian Current Surplus

Based on Reserves as at June 30th, 1966

Bcf at 1,000 Btu/cf

Available Reserves

Established reserves ................................. 47,997

Less beyond economic reach ................... $(2,834)$

Less deferred for conservation ................ $(3,831)$

Total contractable reserves: ............ 41,332

Plus remaining imports under existing licences ................................ 316

Requirements

Canada ....................................................... 25,160

Existing export licences .......................... 10,869

Exports then under consideration

Westcoast .......................................... 3,185

Alberta and Southern ..................... 1,952

Canadian-Montana ............................... 241

Canadian Surplus:

The Board then went on to say:

The Board has also considered the arguments advanced for determining current surplus on an all-Canada basis rather than on a regional basis. The Board believes that the surplus determination must be made in such a manner that any Canadian market now receiving Canadian gas will be assured of protection for its future requirements from its present general supply area, before additional exports are authorized from that supply area.

In the case of British Columbia requirements, the Board concluded that in Westcoast's supply area there would be a current deficit of available reserves in the amount of 587 bcf if the current application were granted.

The Board then went on to make a determination of Canada's future surplus as at June 30th, 1966, summarized as follows:

Canada-Future Surplus as at June 30, 1966

Future Supply Bcf at $1,000 \mathrm{Btu} / \mathrm{cf}$

Available reserves 41,332

Established reserves to become contractable between the 5 th and

20th year

(a) from reserves presently beyond economic reach

(b) from reserves presently deferred for conservation

Trends 2,400 Bcf/year x 20 years ............................. 48,000

Remaining Imports ........................................................ 316

Total:

Future Requirements

Canada, east of Alberta, including terminal year, peak-day protection 
[VOL. IX

Alberta, including terminal year peak-day protection 19,086

B.C., including terminal year peak-day protection (excluding East Kootenay)

East Kootenay, including terminal year peak-day protection

Existing export licences

Exports then under consideration:
(a) Westcoast
(b) Alberta and Southern
1,952
(c) Canadian-Montana
241

Total:

$\overline{89,326}$

Future Surplus:

6,030

It will be noted that the Board assumed that Canadian reserves would appreciate by an average of 2,400 bcf annually over the next twenty years (trend gas).

\section{Requirements}

Basically, "requirements" referred to in the current surplus calculation are those existing reserves set aside to provide a portion of future deliveries and peak day protection for domestic markets plus existing export commitments. "Future requirements" reflect the portion of future reserve additions that must be set aside to cover the balance of these market needs.

In its May, 1967, decision on the application of Alberta and Southern et al, the Board used the same determination of current and future surplus referred to above.

At the recent export hearings, the Canadian Petroleum Association proposed a new method of surplus determination, suggesting that:

(a) deferred gas that will become contractable within the first ten years of the protection period should be considered available for purposes of surplus determination, and

(b) current domestic requirements should be protected by setting aside 25 times first year rather than 4 th year level of requirements.

The method followed by Consolidated Natural Gas Limited also embodied new principles:

Consolidated first projected total energy by province and determined the market share for each relevant energy form.

The residential-commercial sector was tied to a projection of household formations. The industrial sector was related to net value added in manufacturing in terms of 1949 dollars. Natural gas use in the thermal generation of electricity was related to a forecast of provincial electricity use.

Population growth and the resulting number of households were considered in relation to per capita use of energy and the steadily increasing trend in urban living from the single family dwelling to apartment living. An illustration of this trend is shown below:

\begin{tabular}{lll} 
& 1960 & 1968 \\
\cline { 2 - 3 } & & \\
$\begin{array}{l}\text { Single Family Dwelling } \\
\text { Construction }\end{array}$ & $60 \%$ & $40 \%$ \\
$\begin{array}{l}\text { Apartment Building } \\
\text { Construction }\end{array}$ & $40 \%$ & $60 \%$
\end{tabular}

Consolidated stated that the fertility rate is the single most important factor in determining population growth and pointed out that this factor had been declining markedly in recent years. The company assumed this rate would continue to decline by approximately $15 \%$ between 1967 and 1981 and would remain con- 
stant thereafter, which resulted in a Canadian population projection in 1990 about 1.5 million less than the National Energy Board staff projected of 30.4 million. Based on the 1967 to 1968 drop in fertility rates, which was greater than expected, 8 Consolidated estimated that their projection for 1990 could not be considered too high by at least 0.5 million.

Under cross-examination, Consolidated indicated that they had been unable to hold discussions with distributors in Manitoba, Ontario and Quebec. However, they stated that discussions had been held with distributors in British Columbia, Alberta and Saskatchewan. In answer to a question regarding projections of the industrial sector for Eastern Canada, Consolidated indicated that discussions were held with competitive fuel suppliers rather than users.

The Chairman of the National Energy Board questioned Consolidated regarding their relatively low forecast of Canadian gas requirements. Consolidated replied that it is not surprising that their projections appear low. since projections prepared by two other parties had considered natural gas in the isolation of total energy. Consolidated stated that the technique of simply summing forecasts prepared by various utility companies can be hazardous, particularly over a 30-year forecast period.

In discussing projections of gas requirements with Consolidated's witness, the Chairman of the National Energy Board pointed out that no projections over the past decade were high enough to cover the requirements on actual record. Consolidated replied that the period from the middle 1950's to the late 1960's has been a build-up period insofar as natural gas use in Canada was concerned. However, Consolidated considers Canada is now in a more mature period in terms of growth rates.

At another point in the proceedings, it was stated that the National Energy Board staff study, like the one prepared by Consolidated, had been based on a projection of total energy and an allocation of the energy market to various fuels.

\section{Reserves, Deliverability and Trends}

Generally speaking; all parties who gave evidence before the National Energy Board on this topic adopted the same approach. For the purposes of this paper, the Submission of the Canadian Petroleum Association has been selected as typical.

The Association's Reserve Committee conducted a study of the total potential reserves of oil, gas, natural gas liquids and associated sulphur in Canada. The term "potential reserves" refers to estimates of the total amounts of oil, gas and natural gas liquids that can be expected ultimately to be recovered under present day technology and conventional methods of oil and gas production. They include amounts already produced, amounts considered to be proven and probable in known accumulations, and amounts yet to be discovered on the basis of geological evaluation.

The "Volumetric Method" was used in making the estimates of potential reserves. In this method an estimate is made based on available geological data of the volume of sedimentary rocks in a given area. This volume, expressed in cubic miles, is multiplied by a "recovery factor" which is an estimate of the number of barrels of oil believed to be recoverable per cubic mile of sediment. The recovery factor varies from area to area depending on the pertinent geological conditions. In determining the volumes of sediments in Canada, only those sediments in excess of 1,000 feet in thickness, occurring to a depth of 25,000 feet, and occurring in water depth of less than 600 feet on the Continental Shelf, were included in the calculations. Within these limits the volume of sediments in the potential hydrocarbon areas of Canada was calculated to be 2,641,500 cubic miles. An average re-

\footnotetext{
B 1968 data became available after Consolidated completed their forecast.
} 
covery factor of 46,000 barrels of crude oil per cubic mile of sediment was applied.

Having determined the potential oil reserves by the Volumetric Method, the potential gas reserves were then calculated using the ratio of gas discovery-to-oil discovery that has been petroleum industry experience in the past in Western Canada and the United States, and applying this ratio to the potential oil reserves. The ratio of 6,000 cubic feet of gas per barrel of oil was used to forecast the potential gas reserves in Canada.

The sedimentary areas in Canada that were considered in the Committee's study as having potential hydrocarbons include the Western Canadian Sedimentary Basin (Alberta, Northeastern British Columbia, Saskatchewan, Manitoba and the Yukon and Northwest Territories), the Arctic Islands, the Pacific and Atlantic offshore areas, the Hudson Bay region, the Gulf of St. Lawrence and the Maritimes, Southern Ontario and portions of the interior of the Province of British Columbia. Of these regions only the Western Canadian Sedimentary Basin has received any significant amount of exploration by industry to date. Exploration is, however, extending northward in Western Canada and deeper into the Western Sedimentary Basin. At the same time, exploration is accelerating in the Atlantic Offshore and Arctic Islands. Both these regions have favourable geological characteristics similar to other regions of North America where large reserves of oil and gas are known. The Committee therefore anticipated that the potential reserves of these regions will be realized as the level of exploration increases and usual logistics problems associated with remote areas are solved.

To estimate when the reserves would become available, the Committee used an average annual trend calculated on the average of the most recent ten-year period. It contended that this would relate the trend of reserve additions to a current exploration period, minimize the effect of the cyclical nature of discoveries and eliminate the effect of the early history of exploration success in Canada.

\section{The Surplus Calculation}

Having reviewed the Board's past procedures in determining current and future surplus, it may be of interest to examine some of the specific areas where change was recommended.

Once the Board has ascertained Canada's present and future requirements and the reserves available, both actual and potential, it must, as has been pointed out, determine, firstly, whether there is a current surplus of gas beyond the immediate needs of Canadians which can be licensed for export, and secondly, (assuming there is such a current surplus), whether those volumes need be retained as "locked in" to take care of what may be a foreseeable future deficit. Hence, two calculations have to be made under the procedures presently followed by the Board.

It has already been indicated that the Board's method of determining available reserves is to add to its estimate of proven reserves onehalf of its estimate of additional "probable reserves." The Canadian Petroleum Association, on the other hand, calculates the proven reserves discovered to date and upgrades these reserves to what it also refers to (perhaps unfortunately) as a "probable reserve" volume 
based on past historic trends in appreciation to existing pools. (The use of the same defined term by the Board and the Association for different calculations has inevitably caused confusion). In justifying this procedure, the Association points out that the ultimate probable reserves for pools discovered to year end 1962 were estimated at 40.6 TCF as at that date. By year end 1968, these reserves had appreciated to $58.9 \mathrm{TCF}$ or an increase of $45 \%$ over six years.

Acknowledging this difference in approach to the determination of remaining reserves, the Canadian Petroleum Association's probable reserves have nevertheless been used to indicate how the current and future surplus calculation is made. Total remaining reserves were estimated at 60.1 TCF of 1,000 BTU gas. These figures are based on confidential data received from Canadian Petroleum Association members by the Central Reserves Committee of the Association. From this figure the Board first deducts those reserves considered to be beyond economic reach, amounting to 3.6 TCF and those reserves, amounting to 6.4 TCF, the production of which must necessarily be deferred because of conservation requirements, leaving a contractable reserve totalling 50.1 TCF. To this figure is added .1 TCF representing the remaining quantities of gas still to be imported under existing licences. The total available reserves therefore amount to 50.2 TCF.

In determining current Canadian requirements, the Board considers that Canadians outside of Alberta should be "protected" to the extent of 25 times the 4 th year requirement which in this case, based on the Board's own requirement studies, would be .845 TCF per year. The total current requirement for Canada except for Alberta is therefore set at 21.1 TCF. The same protection is afforded for Albertans unless the amount set aside by the Alberta Oil \& Gas Conservation Board (calculated at 30 times the 1st year) should be greater. The 4th year requirement of Albertans is .3486 TCF per year, resulting in a volume set aside for Alberta's requirements of 8.7 TCF. The only additional deduction to be made from the total available reserves is the balance still committed to existing export licences, which for the purpose of this calculation amounts to $12.4 \mathrm{TCF}$. Total requirements from available reserves is therefore 42.2 TCF which, when deducted from the available reserves of $50.2 \mathrm{TCF}$, leaves a current surplus of 8 TCF.

It now becomes necessary to determine whether there will be a future surplus since the existence of such a surplus is a condition precedent to the release of the current surplus for export. As has been seen from the current surplus calculation, the available reserves amount to 50.2 TCF. It must then be ascertained what additional reserves will become contractable by the 30th year. The source of this future supply is threefold: firstly, those reserves presently beyond economic reach, which will become economic within the 30-year period; secondly, the reserves presently deferred for conservation purposes which will be freed from regulatory restrictions during the period, and thirdly, those volumes of gas which can reasonably be expected to be discovered in the future. The Board's present practice is to include $75 \%$ of those reserves presently beyond economic reach as their estimate of the proportion of such reserves which will come within economic reach in the next 30 years. This provides an additional future supply of 2.7 TCF. Likewise, an estimate is made, based on engineering data, 
of the volume of reserves currently deferred for conservation reasons, which will become available within the period. In the present instance this future supply was increased by 5.7 TCF, which is a substantial percentage of the total volumes of deferred gas deducted in the current surplus calculation. The largest addition to the future supply is, of course, attributable to expected trends in reserve additions. The Board's present practice bases these estimates on a projection of the future growth of gas reserves and has predicated the estimates on an anticipated decline in average annual additions. On this basis, the Board projects an average trend of 2.3 TCF per year, which gives a cumulative addition to reserves over the forecast period of 46.0 TCF.

Moving now to future requirements, the Board's first deduction is to cover Canadian requirements except Alberta. In a report of May, 1967, the National Energy Board staff estimated the amount to be 41.3 TCF. The peak daily requirement applicable to those volumes is 2.5 TCF. Requirements for Alberta are 15 TCF with a peak daily requirement in the terminal year of 5 TCF. The final requirement to be deducted from total future supply consists of the remaining delivery commitments under existing export licences, which, for purposes of this calculation amounted to $12.4 \mathrm{TCF}$. It is apparent then that the total future requirements of 76.2 TCF when deducted from the total future supply of 104.6 TCF leaves a future surplus of 28.4 TCF. Since this results in a projected future surplus, the current surplus of 8 TCF becomes available to satisfy any pending export applications.

Having outlined the Board's procedures in determining current and future surplus, consideration can be given to the modifications proposed by the Canadian Petroleum Association. The recommendations with respect to changes in the current surplus calculation will be dealt with first. As previously indicated, the Association contended that its use of proven reserves plus anticipated appreciation based on historical trends is preferable to the method adopted by the Board in using all the proved plus half their estimate of what the Board defines as "probable" reserves. The Association, although deducting from this figure the entire volume of reserves beyond economic reach, expressed the view that the Board would be justified in utilizing a portion of these reserves in the current surplus calculation if such use were ever necessary to avoid a deficiency in the current surplus. The Association argument was that, based on past experience, it is evident that a portion of those reserves which are now beyond economic reach can reasonably be expected to come within economic reach during the next 3 to 4 years. In dealing with reserves deferred for conservation purposes, the Association took a more positive position and contended that those reserves presently deferred for conservation reasons but which can be reasonably expected to become available within 10 years should be included in the supply side of the current surplus calculation. The Association therefore recommended that a deduction of only 2.2 TCF be made from the remaining reserves rather than the 6.4 TCF figure used by the Board. By reducing the deduction for deferred reserves, the total available reserves for the current surplus calculation increased to 54.4 TCF.

In considering the current requirements for Canada except Alberta, it will be recalled that the Board adopts a current requirements protection based on 25 times the 4 th level of requirements. The Asso- 
ciation contended that this calculation actually exceeds that provided by the Province of Alberta of 30 times the 1st year level. The Association pointed out that since the remainder of Canada does not place as great a reliance on gas as an energy source as does Alberta, the Board should protect their current requirements only to the extent of 25 times the 1st year level of requirements. That formula would result in a requirement of only 18.2 TCF rather than the 21.1 TCF figure used by the Board. With respect to Alberta's requirements, the Association also took the position that the protection for current requirements as stipulated by the Alberta Oil \& Gas Conservation Board was sufficient, if not excessive, and therefore reduced the Board's figure of 8.7 TCF (based on 25 times 4 th year) to a figure of 8.5 TCF (based on 30 time Alberta's first year requirement). The requirement to cover existing export licences remained the same at $12.4 \mathrm{TCF}$, leaving a total requirement, according to the Association's estimate, of only 39.1 TCF rather than the 42.2 TCF figure arrived at under the Board's method. As a consequence, using the Association's method, a current surplus of 15.3 TCF results.

Moving now to the future surplus calculation, the Association starts out with an available reserve figure of 54.4 TCF, as compared with the Board's figure of $50.2 \mathrm{TCF}$, to which is added the reserves beyond economic reach and which will become available during the period, amounting to $2.7 \mathrm{TCF}$, plus the balance of reserves presently deferred for conservation which have not been included in the current surplus calculation. The latter represents a volume of 1.0 TCF. The only other addition is trend gas and it is in this area that the greatest divergence appeared between the Board and the Association. Although a 20 year period is used in both calculations, the Association, as has been mentioned, took issue with the Board's projection of future growth of gas reserves which showed a decline in average annual additions. The Association contended that annual additions experienced in the United States in the period 1946-1968, indicated a relatively uniform rate, based on a 10 year moving average. For the period 1946-1955, the average was $14.9 \mathrm{TCF}$, and for the period 1959-1968 the average was 18.7 TCF per year. This indicated, in the Association's view, that in the United States, with its relatively long history, there has been no indication to date of a decline in the rate of annual gas additions. Since development of Canadian reserves is in a much earlier stage than that of the United States, the Association contended that it would be more realistic to base gas reserve addition on recent history. The Association therefore proposed that the average annual trend be calculated on the average of the most recent 10 year period. The Association calculated that the average annual trend in the past 10 years was 4.4 TCF which, when multiplied by the 20 year period, would amount to 88.0 TCF. This compares with a Board figure of only 46.0 TCF based on a 2.3 TCF trend. The resulting total future supply, according to the Association's calculations, was 146.1 TCF.

In offsetting the future supply by future requirements, the Association used the requirements set forth in the National Energy Board report of May, 1967, and Alberta requirements as set out by the Alberta Oil \& Gas Conservation Board. However, the projection period used by the Association was for 25 years only as compared to the 30 year period used by the Board. It is unnecessary to go into details 
relative to the calculation of terminal year peak day requirements. The Association used the Alberta Board's formula to arrive at these volumes. It is apparent that the current surplus calculation is the most important factor in determining whether an exportable surplus exists. Alberta \& Southern repeatedly expressed the view, as did other interested parties, that

The value of the future surplus calculation diminishes as the length of the projection period is increased because of the uncertainties relating to trend gas, energy requirements and the forms of energy which will capture particular markets.

This view had been asserted by them in earlier hearings, when they said that in their opinion:

We are beginning to produce figures of a magnitude and perspective affecting present business which are really getting out of proportion to their meaningfulness, hav. ing regard to the great difficulty of forecasting markets into the 90's and, under such a method, it is also necessary to estimate these terminal year peak requirements. While being quite respectful of the problem of covering this long term requirement of Canada and the licences, we still consider that such a specific approach, using such long term estimates, is much less reliable than the current surplus method and we are apprehensive that it exercises a rigid control over present commerce.

At the recent hearing, Alberta \& Southern went so far as to suggest:

That, in order for the National Energy Board to ensure that adequate gas is reserved for future use in Canada, the Board might employ a "Projected Surplus" calculation which would involve repeating the current surplus calculation as it would be done at a series of future points in time up to ten years.

They contended that "the foreseeable future" could not exceed ten years, and stated that, even if no surplus was projected to exist in the tenth year and if reserve development dropped to zero at that point in time, the Canadian market would be served for ten years at the projected growth rate plus 25 years at a level rate, for a total of 35 years.

\section{E. EXPORT PRICE IN RELATION TO THE PUBLIC INTEREST}

Section 83 of the National Energy Board Act provides in part that the price to be charged by an applicant for gas or power exported by him is to be "just and reasonable in relation to the public interest." The price to be paid by the exporter to the producer appears in the gas sales contracts that are filed as a part of the applicant's case. The price to be received by the exporter from the foreign purchaser is in some cases a fixed price and in other cases a price calculated by the application of a formula. Some of the export companies operate on what is called a cost of service basis, which merely means that to the field price of the gas is added the cost of transmitting the gas from the field to the place of export, the sum of the two figures being the export price. Alberta \& Southern and Consolidated use this method to determine export price. Trans-Canada and Westcoast establish their export price through arm's length negotiations with the foreign purchaser of the gas.

The ceiling price for gas, whether in the domestic or export market, is determined by the price of alternative fuels in the market place, sometimes called the least cost alternative. In many cases consumers are willing to pay a premium for natural gas because of its inherent qualities, but there are definite limits as to the size of the premium, especially in the case of commercial and industrial consumers. Need- 
less to say, the consumers at the far end of the pipeline usually pay more for gas than consumers located closer to the source of supply. We say "usually" because a large volume user at the end of a pipeline could pay less than small volume users located nearer the source of supply. The price to the consumer is therefore related to transportation costs and volume used.

Volume is an important determinant of price. The expression "economies of scale" refers to the fact that the more gas that is carried through a pipeline the lesser should be the unit cost and price. There are, however, also limits to economies of scale.

At the recent hearings, a mass of evidence was led on the question of export price in relation to the public interest. The views of parties opposite in interest to each other appear to be irreconcilable. There were advocates of acceptance of the price set by arm's length bargaining between buyer and seller with a floor price level. There were advocates of the price set by arm's length bargaining between producer and exporter to which is to be added transportation costs to arrive at the export price. There were those who supported the Board's "three normal tests." There were some who argued that free and unlimited competition in the market place would set the appropriate price and that the Board should only concern itself with the prevention of dumping. And there were some who directly or indirectly advocated a two price system through government regulation, with the highest possible price from time to time to be obtained for gas exported, with some of the funds being diverted to keep the price to Canadian consumers at a low level.

The National Energy Board is charged with solving the problem, and it must be guided by the public interest. What is the public interest? Who is the public? There are few reported decisions dealing with the words "the public interest" and none that are of any real assistance to an interpretation of the meaning of the words. Parliament has charged the National Energy Board with the task of interpreting and applying the test of the public interest in the factual situations that come before it. It is not an easy task and many millions of dollars are involved in virtually every gas export application.

Probably the only unanimous agreement to come out of the hearings was that the export gas should be sold at the highest possible price. Even here, one could sense a certain reluctance on the part of some of the export companies to agree that the highest possible price would always be in the public interest.

One of the better statements of the law with regard to the public interest is to be found in Mason v. Provident Clothing and Supply Company, Limited. ${ }^{9}$ This case was concerned with the interpretation of a restrictive covenant not to carry on business for a period of three years in a given area. Lord Shaw of Dumferline referred to Lord McNaughton's opinion in Nordenfelt v. Maxim Nordenfelt Guns and Ammunition Co. ${ }^{10}$ and said as follows: ${ }^{11}$

I cannot refrain from again quoting Lord McNaughton's words: "The true view at the present time, I think, is this: The public have an interest in every person

\footnotetext{
$"[1913]$ A.C. 724.

III [1894] A.C. 5335 .

"Supra, n. 9 at 739.
} 
carrying on his trade freely: so has the individual. All interference with individual liberty of action in trading, and all restraints of trade themselves, if there is nothing more, are contrary to public policy, and therefore void. That is the general rule. But there are exceptions: restraints of trade and interference with individual liberty of action may be justified by special circumstances of a particular case. It is a sufficient justification, and indeed it is the only justification, if the restriction is reasonable-reasonable, that is, in reference to the interests of the parties concerned and reasonable in reference to the interests of the public, so framed and so guarded as to afford adequate protection to the party in whose favour it is imposed, while at the same time it is in no way injurious to the public." I have referred, my Lords, to the apparent antagonism between the right to bargain and the right to work. The extreme of the one destroys the other. But the public interest reconciles these two, and removes all antagonism by the establish ment of a principle and a limit of general application.... In every case in which it exceeds that protection, the public interest, which is always upon the side of liberty, including the liberty to exercise one's powers or to earn a livelihood, stands invaded, and can accordingly be invoked to justify the non-enforcement of the restraint.

Viscount Simmon L.C. in Duncan v. Cammell Laird \& Co. said:12

After all, the public interest is also the interest of every subject of the realm, and while, in these exceptional cases, the private citizen may seem to be denied what is to his immediate advantage, he, like the rest of us, would suffer if the needs of protecting the interests of the country as a whole were not ranked as a prior obligation.

Burrough J., as early as 1824, in Richardson v. Mellish, commented on "public policy" in terms that may be applicable to "public interest." He said that "it is a very unruly horse, and once you get astride it you may never know where it will carry you. It may lead you from the sound law. It is never argued at all but when other points fail."13

So, in the last resort, the National Energy Board is left to satisfy itself that the export price is just and reasonable in relation to the public interest. Its task would be greatly simplified if Parliament had attempted a definition of "public interest" or had given the Board some indication of just what it meant by the words.

\section{F. PRACTICES AND PROCEDURES OF THE NATIONAL ENERGY BOARD}

\section{Board Membership}

Although there is presently before Parliament a bill to, inter alia, increase the authorized number of members to seven, the National Energy Board presently consists of five fulltime members appointed by the Governor in Council. Subject to compulsory retirement at age seventy, the appointment is for a term of seven years with the members being eligible for re-appointment. Board members must be Canadian citizens, reside in Ottawa or environs and must not be owners, shareholders, debtholders, directors, officers or partners in any business engaged in any facet of the hydrocarbon or power industries.

The Chairman is the chief executive officer of the Board, having powers similar to those of the president of a corporation. If the Chairman is absent or unable to act, his powers and functions may be exercised by the Vice-Chairman. A quorum of the Board consists of three members. The Board has the power to sit at any place it considers necessary or desirable. When hearings primarily involve matters of local interest or when the holding of hearings in Ottawa would

12 [1942] A.C, 624 at 643

11. (1824) 2 Bing. 229 at 252; 130 E.R. 294 at 303. 
involve undue hardship on parties having legitimate interests in the proceedings, the Board usually conducts its hearings near the locality principally concerned. Hearings have been held in such widely separated points as Fredricton, New Brunswick, and Trail, British Columbia. Hearings that are of national or general interest are usually held at the Board's head office in Ottawa.

\section{Board Staff}

The Board has its own staff, each of whom, other than the Secretary, who is appointed by the Governor in Council, is appointed under the provisions of the Public Service Act and, for the purposes of the Public Service Superannuation Act, is deemed to be a person employed in the Public Service. At present, the Board staff consists of approximately 155 persons including two practising lawyers, twenty engineers, twenty economists and ten accountants. The present members of the Board are:

Robert D. Howland, an economist, Chairman.

Douglas M. Fraser, an economist, Vice-Chairman.

Maurice Royer, a civil engineer.

$H$. Lee Briggs, an electrical engineer, and

Jack G. Stabback, a chemical engineer.

The other principal officers are:

$\begin{array}{ll}\text { Robert A. Stead } & \text { - Secretary } \\ \text { F. H. J. Lamar } & \text { - Chief Legal Counsel } \\ \text { W.A. Scotland } & \text { - Chief Engineer } \\ \text { E.B. McDougall } & \text { - Financial Adviser, and } \\ \text { R. E. Boston } & \text { - Director of Operations }\end{array}$

The office of the Director of the Economics Branch is presently vacant.

\section{Board Powers}

The Board is a court of record having basically all the powers, rights and privileges as are vested in a superior court of record, having full and exclusive jurisdiction over the matters covered by the Act and having all of the powers of commissioners under Part I of the Inquiries Act. The Board may act on its own initiative or upon the request or application of others, and its decisions may be enforced as decrees of the Exchequer Court or of any superior court of any province. Decisions of the Board may be appealed to the Supreme Court of Canada on questions of law or jurisdiction and the Exchequer Court has exclusive jurisdiction on applications for prerogative writs.

\section{Certificates and Licences}

Hearings with regard to the issue, cancellation or suspension of certificates or licences for the exportation of gas or power or for the importation of gas must be held in public.

If one wishes to move gas beyond the boundaries of a single province to one or more other provinces or outside of Canada, one must first have a company, being a person having authority under an Act of Parliament to construct or operate pipe lines, for only such a company is entitled to construct or operate a pipe line and that company must then obtain a Certificate of Public Convenience and Necessity and leave to open its line. Further, if one wishes to remove gas or 
power from or import gas into Canada one must obtain an Export/ Import Licence.

Generally speaking, Certificates of Public Convenience and Necessity are governed by Part III of the Act and Export/Import Licences are governed by Part VI, but in each case reference must be made to the regulations made pursuant to the Act.

\section{Rules and Regulations}

Under the powers conferred by Section 7, the Board has established the National Energy Board Rules of Practice and Procedure ("N.E.B. Procedural Rules") ${ }^{14}$ which, inter alia, include by way of schedule a statement of the Information Required to be Filed by Applicant for Certificate in Respect of Gas Pipe Line and under the powers conferred by Section 85 in Part VI of the Act, the Governor in Council has made the National Energy Board Part VI Regulations ("Part VI Regulations")15 which include procedure to be followed and information to be furnished for the carrying into effect the purposes and provisions of Part VI.

\section{Comment}

The Board, being an administrative agency has provided in Rule 3 of the N.E.B. Procedural Rules that it may direct that the rules or any of them shall not apply in any specific hearing or that it may substitute other rules for the established rules. This obviously has left the Board with a great deal of flexibility in the matter of determining practice and procedure before it. However, the provision for such flexibility has left the system open to abuse by applicants and intervenors appearing before the Board in furtherance of their own self interests.

As lawyers trained to seek uniformity and certainty in the administration of the law and taught that justice must be done but must be seen and seem to be done, we share the concern that has been expressed over the uncertainty and lack of uniformity that is apparent, from time to time, in the practice and procedures of administrative agencies, including the N.E.B. However, as pragmatists, we must admit that before the N.E.B., the abuse of which we speak has, to date, been kept to a minimum and we attribute this to two principal factors:

(1) strong, fair and impartial board members, and

(2) the realization by applicants and intervenors that the shoe may be on the other foot at the next hearing.

\section{G. PROCEDURE}

\section{Applications}

To implement the corporate decision to move gas beyond boundaries of a single province it is necessary to initiate, inter alia, N.E.B. proceedings. Rule four of the N.E.B. Procedural Rules states in subsection one that:

Every proceeding before the Board upon an application shall be commenced by filing with the Secretary an application in writing signed by the applicant or the applicant's solicitor.

Parts III and VI of the Act provide in effect that Certificates of Public Convenience and Necessity and Export/Import Licences are to be ob-

1" See Lewis and Thompson, Canadian Oil and Gas, Vol. 2, Div. D, No. [13B].

"Id., No. [13]. 
tained by an application made by the interested party. Subsection two of Rule four states that all applications shall:

(a) contain a concise statement of the facts relevant to the application, the provisions of the Act under which the application is made and the nature of the order applied for;

(b) be divided into consecutively numbered paragraphs, each of which shall be confined as nearly as may be to a separate and distinct portion of the subject of the application; and

(c) be endorsed with the name and address of the applicant or the applicant's solicitor to whom communications may be sent.

Unless the Board otherwise orders, an application for a Certificate of Public Convenience and Necessity to construct gas facilities must contain the information required by Part I of the Schedule to the N.E.B. Procedural Rules and must be accompanied by a map drawn to scale of not less than one inch equals one mile showing the general location of the proposed line, the termini, and all cities, towns, villages, railways and navigable waters through, under or across which the line is to pass. In addition to filing not less than sixteen copies of the application and map with the Board, the applicant must file a copy thereof with the Attorney-General of each province to which the application relates.

The information required to be set out in an application for a $\mathrm{Li}$ cence to Export Gas is described in Regulation 4(2) of the Part VI Regulations and for an application for a Licence to Import Gas in Regulation 5(2).

The practice in preparing an application for a Certificate of Public Convenience and Necessity or Export/Import Licence, or both when they are combined in a single application, is to turn to the requisite schedule or regulation and, following the direction dictated by Rule 4(2) of the N.E.B. Procedural Rules to provide in clear and concise language the information required to be furnished. In this respect, the practice is similar to that followed on the preparation of a prospectus and, as in securities practice, the aim should be to provide full, true and plain disclosure of all relevant and material facts.

Upon the filing of an application the practice followed by the N.E.B. is analogous to that practiced by the various provincial securities commissions. The N.E.B. and its staff review in detail the application and then, under the powers set forth in Rule 5(3) or Regulations $4(1)$ or $5(1)$, send to the applicant a deficiency letter wherein deficiencies in the application are pointed out and elaboration or new information is requested. When the deficiencies have been satisfied, the Board sets the application down for hearing and the Board's Secretary notifies the applicant of the time and place fixed for the hearing and the persons to whom and the manner by which the applicant is to give notice. In addition to any special notice requirements determined by it, the Board generally requires that notice be given by publication in specified newspapers four weeks in advance of the hearing date.

Attention should be given to Rule 18 which provides that, with leave of the Board, evidence, reports, findings or orders from other hearings before the Board or hearings before provincial tribunals for authority to remove gas from a province may be evidence at the 
hearing of the application. If such leave is to be sought it should be requested in the application itself.

\section{Interventions}

The public notice specifying the nature of and the time and place for the hearing of the application will specify a time within which interested parties may file a reply or submission and on whom copies thereof are to be served. A reply made by a respondent or a submission made by an intervenor must be signed, must contain a concise statement of the facts from which the nature of the party's interest in the proceedings may be determined and must contain an address for service. Fortunately, these compulsory requirements are easily met. Although a reply or submission may admit or deny any or all of the facts alleged in the application, it is often not possible to make such permissive pleadings. Many interventions, particularly those relating to complex hearings, are prepared and filed without reference to or only after a cursory review of the actual application. This is so, because time and monetary considerations do not always permit a trip to Ottawa to review the public files of the N.E.B. or the correspondence with the applicant's head office. Also, because applications of an involved nature are usually prepared and filed only after extensive research and consultations with the Board staff, an intervenor often does not have the time to obtain a proper appreciation of the issues arising from the application before the deadline for filing. Notwithstanding these limitations on the use of permissive pleadings, intervenors should be aware of the right to make them, for the Board appreciates receiving advance notice of an intervenor's position when it can be given and will entertain challenges as to law or fact raised by an intervention. The Board's attitude towards an intervenor is governed by its assessment of the relevancy and seriousness of the intervention. To be taken seriously at a hearing, an intervenor should have its own policy and expert witnesses and, if during the hearing it is decided not to lead evidence, the intervenor should advise the Board that such witnesses are available, should the Board wish to question them with regard to any of the issues raised during the hearing.

Although the foregoing briefly outlines the correct procedure for intervening, one should realize that the Board does not always follow its own Rules. Basically, to date, the Board has been prepared to accept any form of written communication evidencing an interest in or position concerning an application and to hear any party that has cared to attend at the hearing. Although we acknowledge the great expertise and experience of the Board and its staff, we find this de facto practice of the Board objectionable and think it to be unfair as it allows in as evidence untested statements and opinions. When meeting this argument, the Board has stated that it attaches "appropriate" weight to such untested statements, but unfortunately no applicant or intervenor has the slightest idea of what is the "appropriate" weight. However, intervenors should bear in mind that it is the formal record of the proceedings that governs in the final analysis and that to have their interventions given thoughtful consideration they should proceed formally as outlined above.

\section{Conduct of Hearings}

At the hearing, applicants and interested parties may be represented 
by counsel or may represent themselves. The hearings open with the recording of appearances, followed by the applicant formally filing, for the record, the application and supporting documents. When these filings have been completed, the intervenors should file formally, for the record, a signed copy of the intervention and an affidavit of service. The formalities thus completed, the hearing proceeds in the usual manner, that is
(a) the applicant leads its evidence in chief,
(b) the intervenors, in alphabetical order, cross examine,
(c) the Board Staff and the Board ask questions,
(d) the intervenors lead their chief and reply evidence,
(e) the applicants and other intervenors cross examine,
(f) the Board Staff and Board ask questions,
(g) the applicant leads his reply evidence,
(h) the intervenors cross examine,
(i) the Board Staff and Board ask questions,
(j) the applicant presents argument,
(k) the intervenors present argument, and
(1) the applicant presents reply argument.

\section{Comment}

As an administrative agency the N.E.B. is impressive. Under its guidance the hydrocarbon industry has flourished. Hearings before it have been well run, and all interested parties have been permitted to present their views. Without limiting these tributes, it is our opinion that there is substantial room for improvement on a procedural level.

To an applicant or intervenor the hearings are often lengthy and always expensive. Applicants must wait for the hearing before knowing what arguments of intervenors they must meet. Before the actual presentation of an intervenor's case, neither the applicant nor other intervenors are in a position to gather and assess information to support or attack the case. Intervenors must wait for oral testimony to understand how the applicant intends to support the information set out in the application. Without any preparation time, it is difficult if not impossible to effectively challenge expert testimony carefully prepared over many weeks. This leads to a suggestion that the N.E.B. consider the use of "canned" testimony, that is commission evidence, for the applicant's and intervenors' cases in chief. This is, of course, an adaptation of F.P.C. practice and before the suggestion was accepted, it would be necessary to study the effectiveness of the F.P.C. practice and to solicit the views of all of the segments of the Canadian industry.

The present N.E.B. practice is to have witnesses questioned by counsel who are briefed by industry experts. Often this is ineffective and more apt to cloud than to clarify the issues. Expert witnesses should be cross-examined on technical matters by like experts. This is not to say that an applicant's or intervenor's case would not be conducted by counsel but rather that, under the general supervision and guidance of counsel, those portions of a case where the evidence is particularly complex, calling for detailed expert knowledge of a specialized field, be challenged on cross-examination by a person possessing such knowledge.

To expedite hearings the N.E.B. could make use of the staff con- 
ference device used so successfully by the Alberta Oil \& Gas Conservation Board. This device allows an objective search for what should be non-contentious information, such as reservoir porosity or permeability, to be made outside of the actual hearing. Only those parties interested in such information need appear at the staff conference and others may simply accept the verdict arrived at from such conference.

The practice, followed by the Alberta Oil \& Gas Conservation Board and the N.E.B. at the recent gas export hearings, of sitting in the morning only, commends itself in contested hearings as a pattern for the future. It allows daily transcripts to be delivered at a reasonable hour, time for intelligent reflection on the day's proceedings, time to adjust one's own case to meet any unanticipated events and last, but not least, time for a decent night's sleep so that one may be alert during the next day's proceedings.

Having made these few suggestions, we would like to repeat that we are impressed with the workings of the N.E.B. and would not like to see the existing procedures altered drastically, except following meetings at which the N.E.B., its staff and all segments of the industry have been afforded an opportunity to exchange their respective views.

\section{H. POSITIONS TAKEN AT THE RECENT HEARING}

\section{The Provincial Governments}

The provincial governments of British Columbia, Alberta, Saskatchewan, Manitoba, Ontario and Quebec filed interventions and were represented. The degree of active participation varied from Alberta which led the evidence of six witnesses, to Saskatchewan, which restricted itself to argument in the final "argument phase" of the hearing.

As might have been expected, the evidence, the argument and the tenor of cross-examination reflected, for each provincial government, the self interest of the province concerned. In this respect, the governments were not unlike the corporate parties represented at the hearing, each of whom, quite properly, advanced its own corporate self interest. The self interest of any particular province is, of course, largely dictated by its geographical location, for location dictates whether it is a have or a have not province in terms of gas reserves, the cost of gas to its consumers (which depends in large part on pipeline miles), the significance of gas to provincial revenues and to industry in the province, the cost and availability of other sources of energy, and so on.

The different positions were most evident, and one might almost say that the issue was joined, on the question of price regulation. The Board specifically referred to price in the policy letter:

1. Methods and assumptions appropriate to the determination of:

(d) the justness and reasonableness in relation to the public interest of the price to be charged by an applicant for gas exported by him;

2. The feasibility of protecting the public interest in respect of the price to be charged for gas exported, having regard for changing price levels from time to time, by instituting procedures such as:

(b) price escalation at fixed periods;

(c) price determination at stated intervals in relation to specified indices.

Inevitably, price questions also arose in connection with the other 
policy topics, because the reasonably foreseeable requirements for Canada, the gas reserves in Canada, and the surplus remaining for export are all determined in some degree by price-that is to say, the field price, the price to the consumer and the cost to the consumer of alternate sources of energy.

British Columbia and Alberta contended that there should be no price regulation directly or indirectly at any point in the chain from producer to consumer, and that the Board should confine its scrutiny of price to only that degree which is necessary to prevent dumping into the United States markets. Manitoba, Ontario and Quebec advocated some type of "protection" for Canadian consumers against "unreasonable" increases in price. Thus, two "camps" developed, with Saskatchewan remaining relatively neutral.

In general, it is probably safe to say that on questions of price, most of the parties represented at the hearing fitted into one or the other of the two camps. Thus the producers and producer associations were of the same view as British Columbia and Alberta, while the eastern distributors sided to a large degree with Manitoba, Ontario and Quebec. The position of the applicants cannot be labeled quite so neatly, although in general, one found Alberta and Southern, Consolidated and Westcoast in the "Western camp," with Trans-Canada, being the only supplier to eastern Canada, trying to be a member of both groups. Trans-Canada predicted that it would have "excess profits" from export sales which would be passed on in part to consumers who purchase from Trans-Canada and in part to producers in the form of higher field prices. In this fashion, they could be benevolent to both producers and consumers, i.e., to both "camps". Contrast these two statements from the rebuttal argument of counsel for Trans-Canada (at page 6089 of the transcript of proceedings):

There was another argument advanced by my friends from the producing industry, that increases in field prices would not adversely affect the price to gas consumers. In my respectful submission, this statement echoes the views of the producers who do not understand the problems of distribution companies. Their views on this point, that is the distribution companies' views on this point, should be respected, and I particularly commend the experience of Mr. Learoyd of Union Gas to you. That witness stated that a very small change in the price of gas could cost Union an industrial customer, and unless the proper balance is maintained between residential, commercial and industrial loads, Union Gas loses its flexibility in its purchasing practices. Loss of industrial loads can and will increase the cost to the residential and commercial users which is far out of proportion to the unit increase per mcf which caused the loss of the initial industrial load. You just can't say, well, if fuel prices go up two cents, that brings it up to 20 cents in Alberta and what are you doing in Montreal-you are raising it from $\$ 1.22$ to $\$ 1.24$, but that is not the consequence at all. That 2 cent increase could cost Northern and Central a vital industrial load like INCO or Abitibi or one of the major users of energy, and once they have lost that load this is going to affect their entire flexibility in their operations, and it may very well, as Mr. Learoyd said, result in substantial increases in prices to the residential and commercial users who, of course, must absorb the difference.

And at page 6093:

We have got back again to another matter which excites the producers out of all reason. That is this question of wellhead price controls. I would ask my friend, Mr. Gibbs to bear the message back to Alberta that Trans-Canada Pipe Lines Limited does not now, nor has it ever advocated wellhead price controls. So please stop beating us with that stick, because we have never advocated it and we don't advocate it now.

The concept of "wellhead price controls" or, more accurately, "field 
price control" was the central issue between the have and the have not provinces. It is difficult to understand how any method of export price control can avoid being reflected back to the field price. It is equally difficult to understand how any method of subsidy to consumers out of money received from export sales can be other than an indirect form of field price control. Any two price system or method by which an export company has the power, in its discretion, to divide a fund between producers and consumers is also a form of field price regulation. And the inevitable result of any scheme which interferes with the normal business processes and with the free functioning of the market place is a gradually increasing control and manipulation by government and government agencies. So although there was a veritable chorus of denials that anyone wanted field price controls, the parties putting forward the various schemes for consumer "protection" were, in fact, advocating it in some degree, and in many cases were inviting federal government interference to a greater degree than has heretofore existed.

Although the Board may not have intended that field prices would be a matter for debate at the hearing, the Government of Ontario made it clear that it considered field prices to be in issue, as witness these excerpts from its intervention:

The Attorney General asserts the public interest of consumers in Ontario in securing the continued availability of gas from Western Canada at laid-down prices in Ontario that are as low as possible during the term of the licences applied for and thereafter, as far as the jurisdiction of this Board can ensure.

The Attorney General submits that the terms and conditions of the export licences in question should be so fixed as not to cause an undue increase in the field price of gas to the ultimate detriment of Ontario consumers so far as the jurisdiction of this Board can ensure.

The Attorney General submits that in determining the justness and reasonableness in relation to the public interest of the export price for gas to be charged by an applicant for an export licence, this Board may, under Section 83 of the Act, properly have regard for,

(a) any past or future affectation on the field price of gas for domestic consumption in Ontario caused by the terms and conditions at which the gas for export is purchased in the field by an applicant for export... .

The Government of Alberta expressed its concern in its intervention by saying:

The Government of Alberta recognizes that the National Energy Board has not to date regulated export prices for natural gas to the extent that such regulation would appreciably affect the well head or field price for gas. The Government is fearful that the regulation of the well head price would adversely affect exploration and the ultimate utilization of gas, as has apparently been the case in the United States, and urges that the National Energy Board, in discharging its responsibilities with respect to the price charged for exported gas, in no way interfere with the well head or field price for natural gas.

Probably the best way of illustrating the position of each provincial government on this issue is by appropriate quotes from evidence or argument. Thus, British Columbia, through the Honourable Mr. Frank Richter, Minister of Mines and Petroleum Resources (at pages 5320 and 5321):

As to the justness and reasonableness of price, being a free enterprise economy, it is the government of British Columbia's opinion that arm's length bargaining between the producer and purchaser results in the optimum wellhead price. In so far as export price is concerned, my government feels that the current criteria being used by the Board produces a price that is just and reasonable. 
The government of British Columbia would view with considerable concern any control which might reflect on the price to be paid at the wellhead because such control would have an adverse effect on exploration and would directly affect revenue accruing to the provincial treasury.

It is fully recognized by the government of British Columbia that the needs of eastern Canada for assured supplies at fair prices of western Canadian natural gas must be met. The needs of that market, however, ought not to be the reason for asking producers or other consumers in Canada to subsidize by any device the delivery of gas to eastern Canada. Sad to say, history shows that the general policies of national governments have consistently favoured the central provinces at the expense of the western provinces. To require any further contribution at the expense of western Canada and in particular at the expense of British Columbia for the benefit of the central provinces will discourage our own development and would not be welcomed by the government of British Columbia.

Alberta, through the Honourable A. R. Patrick, Minister of Mines and Minerals (at page 1039):

I want to make it abundantly clear that what I am saying is that the province of Alberta has the responsibility of developing its resources and in doing so our interpretation of that is that it is the government of the province of Alberta's responsibility to look to that development in every phase including the field price, and as far as the province is concerned, we would naturally not brook any interference with the establishment of price from outside the province.

and through its counsel, in argument (at pages 5994, 5995 and 5996):

Turning now, sir, to the other part of Section 83 , that is to say, the duty cast upon the Board to satisfy itself that the price to be charged by an applicant for the gas exported by him "is just and reasonable in relation to the public interest," the first point we wish to make on those words, Mr. Chairman, is probably self-evident. That is, that there is no connotation implying a right or duty to look at price in Canada, whether it is at the wellhead or the plant outlet or the burner tip or at any point on the transmission line. It is the price charged to a purchaser for gas leaving Canada which the Board must satisfy itself to be just and reasonable and in the public interest.

In our respectful submission, again as stated by the Honourable A. R. Patrick at page 1011, the function of the National Energy Board should be to see "that there is a just and reasonable price, and that such things as dumping will not occur." And at page 1013 he referred to the export price and stated that it "should be settled in the market place and at arm's length between the parties."

Saskatchewan, through its counsel, in argument (at page 6049):

It is recognized that to date the National Energy Board has not regulated export prices for natural gas to the extent that such regulation would appreciably affect the wellhead or field price of gas. In fact, whether or not the National Energy Board has the constitutional powers to regulate wellhead price remains an arguable question. Without accepting either side of the argument, it is our position that at this time regulation of the wellhead price would adversely affect exploration and the ultimate utilization of gas. It is, therefore, our recommendation that the National Energy Board, in discharging its responsibilities in relation to the applications before it, should in no way interfere with the wellhead or field price of the gas.

Having regard to the foregoing, so far as export price is concerned, our position is that the current criteria being used by the Board produces an export price that is just and reasonable and in the public interest, and that any criteria in the future to be applied by the Board should be determined by the circumstances of the application concerned, having regard to the broad general principles heretofore referred to.

Ontario, through a witness qualified as an expert economist (at pages 2698,2699 and 2760 ):

It is recognized that under conditions of imperfect competition profits from marketing Canadian natural gas may be increased by adjusting the mark-up in each market according to prevailing elasticities of demand. In order, however, to avoid that such profits benefit private interests only, it is essential to share benefits in the form of profits exceeding a fair and reasonable return with public interests in an equitable 
manner, since the public, in purchasing natural gas, is required to assume any costs incurred by those competing for Canada's diminishing non-renewable natural gas resources at the wellhead regardless of where these resources will be ultimately marketed. Accordingly, whether or not this Board accepts or rejects the detailed approach to follow, it is recommended that further criteria be considered in order to protect domestic gas consumers from excessive field price escalation. If Canadian natural gas could, at any time, be marketed in export markets more profitable than domestically, the portion of export income exceeding a fair and reasonable return should be redistributed in Canada for the benefit of present and future natural gas consumers. Failure to protect domestic natural gas consumers in a certain manner may result in a diversion of domestic natural gas into export markets and in a contraction of domestic markets. The protection of public vis-a-vis private interests may be achievable in different ways, such as natural gas field price regulation, a multi-price system, et cetera.

In view of attempts made by government to curb inflationary pressures, for instance, situations may arise where even contractual interference through government may be justified, particularly with respect to price escalation clauses, no matter whether these clauses are contained in contracts between producers and transmitters or transmitters and distributors or anywhere else in the economy. If I may perhaps elaborate on it, I do believe that price escalation clauses are no satisfactory and adequate substitute for governmental and/or regulatory judgment and expertise and with respect, I submit that in cases where price escalation clauses do not bear any relationship between the actual development of all factors in a market, that in such cases I am unable to subscribe to the justification of price escalation clauses.

and through its counsel, in argument (on pages 6026 to 6029 inclusive):

No export policy should be adopted that does not recognize the inter-action of prices and requirements in the surplus formula, and the presence of regulatory jurisdiction over the interprovincial transmission and intra-provincial distribution of gas and the absence of any direct regulatory pricing jurisdiction over the production of gas. It is submitted that the emergent U.S. gas demand will carry with it a continuing preparedness to pay a sufficiently high price for the gas in surplus that gas, once priced out of the eastern Canadian market will remain that way. It is submitted that such U.S. demand results in a new dimension or fundamental change in the economics of the gas industry in Canada, and the U.S. gas shortage is not, in our submission, a near term or temporary phenomenon. And because of this, this Board is respectfully asked to examine the question whether regulation of the export quantity and price per se, if indeed they did operate in the past to stabilize or control field prices, will continue to do so in future. It is submitted that the quantities to be exported bear such a large proportion to Canadian domestic requirements for the foreseeable future that export policies affecting wellhead prices only indirectly may not be sufficient.

As always, there is the fundamental interest of the government of Ontario in the continued supply of ample quantities of gas at reasonable prices. In this, the province asks that the interests of its, and indeed all, Canadian consumers be protected by the adoption of positive policies to preserve to Canadian consumers the future option of using natural gas and to maintain the energy balance and price relationship of gas with other fuels in Canada. It is not enough to rely upon the premium that consumers would be prepared to pay for the premium qualities of gas.

In as much as we are here dealing with a depletable, non-renewable resource, the full potential value of Canadian gas in export markets should be insisted on along with the adoption of additional policies within the limits of the Board's jurisdiction to minimize the inevitable increase in the price of gas to Canadian consumers as prices to producers rise.

And Quebec, through its counsel, in argument (at pages 6040, 6041 and 6042):

Thirdly, surplus remaining after making due allowance for Canadian requirements.... The purpose is not, as has been claimed by the Canadian Petroleum Association and others, to provide for a period of protection sufficiently long to enable industry and other consumers to convert to other forms of energy. On the 
contrary, the purpose is to ensure to the Canadian consumer supplies of natural gas for an indefinite period so long as demand exists and there are supplies available. This is the very essence of the office of the Board-to ensure this protection for Canadian needs in face of the competition offered by the very lucrative export market.

Fourthly, price of export gas and terms of the export permit. It is in the Canadian interest, Mr. Chairman, for prices paid for natural gas destined for export to be as high as possible, negotiated at arm's length and subject to the criteria imposed by the Board in every case in which such criteria can reasonably apply. As a safeguard, the Board could stipulate that export contracts be submitted to mandatory renegotiation of price at fixed periods, and include escalation clauses based on changes in the general price structure. As for the term of the permit, it would not seem equitable to establish it at less than 25 years if the cost of the pipeline and other installa. tions has not been completely recovered or for the term of the contract if it should be less.

Manitoba made very little direct reference to price in argument and it led no evidence. Its identification with the Provinces of Ontario and Quebec was, however, evident through the tenor of the crossexamination by its counsel of the various witnesses called by the other parties.

It is believed that the contents of this section set forth the views of the provincial governments. The Board must now don Solomon's cloak and reconcile them, a formidable task indeed.

\section{The Consumers}

The major areas of concern shared by the users of gas could be summarized within either or both of the following broad generalized categories:

(a) assurance of adequate future supplies of gas at reasonable prices to meet service of existing markets over a reasonable period of time, expansion of existing markets and attachment of new markets,

(b) maximization and spreading of the benefits to be achieved by export sales to the advantage of Canada, the consumers and the producers.

Although having these concerns, the gas customer is not unmindful of the overall need to develop all segments of the Canadian gas industry from production through to burner tip, and that any stand taken on the policy issues raised by the Board would have to balance the interests of all.

Under the heading "reasonably foreseeable requirements" in the Board's letter, the distribution companies advocated that regular periodic hearings for the determination of Canadian requirements are essential. In arriving at this opinion, the consumers of gas were impressed by the fact that the bulk of the long term forecasts filed from time to time with the National Energy Board have under-estimated actual requirements as they have developed. The current concern and crisis regarding pollution will probably see a continuation of this record. In the hope of assuring an adequate supply of domestic gas to service both their existing markets, including new uses for gas, the expansion of those markets and the acquisition of new markets, the distribution companies would like to see formal regular periodic upgrading of long term forecasts which they acknowledge are essential if long-term planning is to be successful. Because the distribution companies are most clearly allied with the end use of natural gas, they are of the opinion that the short-term forecast prepared by them provides a more realistic estimate of short-term Canadian requirements and, accordingly, that the Board should pay particular attention to 
short-term forecasts and the trends ascertainable therefrom presented by the distribution companies.

On the matter of "gas reserves, deliverability and trends in discovery in Canada", the distribution companies are apprehensive over the effect of following some of the recommendations that would include in the calculation of reserves the hypothetical or probable reserves that may be discovered throughout Canada in years to come. This concern was heightened by the fact that the United States is currently undergoing a severe shortage of deliverable gas while the hypothetical reserves for that country are substantial. It is felt, when considered in the light of the current huge demand for Canadian gas in the United States, that if the National Energy Board were to take into account these hypothetical reserves in Canada, in a very few years the Canadian consumers of gas would find themselves in a shortage position insofar as actual deliverability of gas is concerned, although the hypothetical reserves of the country would, undoubtedly, have been substantially increased. Also the complete lack of information relating to economic feasibility of recovering and delivering probable reserves caused suspicion as to the effect of including them in the Board's formula.

At the outset of the hearings, the distribution companies' viewpoint on the calculation of surplus for the purpose of export was unclear to the extent that so long as adequate gas supplies were assured to the distribution companies they were prepared to listen to suggestions for improvement in the formula used for calculating such surplus. As the hearing progressed, the viewpoint changed to one of full-hearted support of the Board's present formula for calculating surplus in that

(a) there was no substantial evidence that there had been any significant volume of gas locked-in,

(b) reserves had increased substantially under the auspices of the Board,

(c) producers have been and are encouraged to explore and develop additional reserves,

(d) distribution companies have had adequate gas supplies to service their expanding markets, and

(e) revenues from the export of gas from Canada have grown substantially.

In view of these conclusions, distribution companies, almost unanimously, supported strongly the recommendation that the Board adhere to its present formula for calculating exportable surplus. In addition, there was the feeling that, with the potential of exporting to the gas-starved U.S., surplus calculated in accordance with this formula would result in added incentive for producers to go out and find additional reserves.

The distribution companies also are of the opinion that the production side of the industry has been substantially developed under the protective policies of the National Energy Board that limited the imports of gas to only such quantities as could not be supplied by domestic gas, and now that the U.S. market has turned and there is a readily available and willing market south of the border, the National Energy Board should not revise its protective policies or recommend changing the nationalistic philosophy apparent in the Act by allowing gas to be exported from the country to the detriment of those users of gas that were compelled to take Canadian gas when it was a more expensive commodity than imported gas. 
When dealing with "export prices and conditions for licences", the distribution companies were of the opinion that negotiated opportunity price was far more advantageous both to them and to the Canadian economy than cost of service price. It is felt that the cost of service basis of supplying gas south of the border allows incremental savings to accrue to American users or parent companies rather than to the Canadian economy or transmitter of gas where the incremental value would be added to taxable income or be available to pay higher field prices to producers and/or reduce costs to end users. In an attempt to cause the export price to reflect commodity value over the term of the contract, the distributors favoured either price re-determination at periodic intervals or floor-price clauses giving a contract price below which the export price of gas may not fall, such floor-price generally being recommended as the price charged for gas in a comparable rate zone in Canada plus a small percentage premium. Distribution companies mainly recommended that short-term export licences not be granted except in unusual circumstances and that existing pipeline companies that are the present suppliers of domestic users be authorized to export gas from Canada. All distribution companies acknowledge that the Alberta and Southern system, which is mainly an export system, must be supplied with gas if it is available for export in order to satisfy the obligation that exists upon Canada, having created a market in the United States dependent upon our gas. On the priority level for export of gas, distribution companies tended to be unanimous in believing that there is an obligation to service old export customers before taking on new ones, and that there was a particular obligation to service export markets that had been built on the strength of Canadian gas and that are solely dependent upon it for supply of gas. Following the meeting of such priority the distribution companies believe that export gas should be made available to service the expansion requirements of existing markets presently served by Canadian gas but having alternative sources of gas available, and that the last priority should be granted to exports to markets not presently supplied by Canadian gas. By recommending that at the present time Export Licences be only granted to pipelines that also serve Canadian requirements, the distribution companies were particularly concerned with the fact that their earnings and prices were regulated, as are those of the transmission companies, and that any profit to be gained on the export of gas should be passed into the regulated section of the industry from which it may be distributed either. by way of consumer price reduction or increased field price to producers.

Part of the concern expressed by the distribution companies that resulted in their opposition to the Consolidated applications was the fact that in the relatively short period during which Consolidated had entered into gas purchasing in Alberta, field prices had increased by approximately $14.5 \%$, and the resulting fear that if Consolidated should be licenced it would be able to offer an increasing premium price to fill its pipeline with incremental volumes of gas while still reducing its landed cost of gas in the United States. If this were so, the domestic transmission companies would have to pay the same premium prices, would suffer a loss of export revenues and would therefore result in the Canadian user of gas making up the lost profit as well as paying for the extra field price. If this situation were to develop, the dis- 
tribution companies feel that there would be no alternative but to impose field price control of gas in Canada-a step that they are reluctant to take at this time.

In summary, one can state that the distribution companies consider natural gas in Canada a national reserve on which Canadians have first call with only those quantities that are surplus to the Canadian requirements over the foreseeable future being available for export, and that any quantities so available for export should be sold on the best terms possible to increase the benefits entering the Canadian economy by way of taxes, reduction of consumer prices or increase of field prices.

\section{The Producers}

The major concern of the producers centred on the need for free competition in the sale and purchase of gas at the wellhead. There was evident fear that any policy adopted by the Board which would preserve specific marketing areas for particular transmission companies to the exclusion of competitive purchasers, would place producers at the mercy of those purchasers in the negotiation of price. In the area of reserves and requirements, the producers considered the Board to be too conservative in its assessment of the former and perhaps too liberal in its estimates of the latter.

In addition to the specific recommendations already referred to in the section on reserves and surplus, the Canadian Petroleum Association urged the Board to continue to recognize two very important considerations, namely:

(i) to calculate surplus in a way which "will minimize to the greatest degree possible" the setting aside of reserves in excess of those for which Canadian purchasers are prepared to contract; and

(ii) to encourage to "the greatest possible degree" competition in the buying and selling of gas at the wellhead.

The C.P.A. contended that this would assure a just and reasonable export price and one "which will be defensible to foreign consumers" because of the incentive provided to producers to search for a new supply. The Association stated that gas producers are not unaware of the concern of Canadian consumers that increased competition may exert upward pressures on domestic prices. However, the Association cited evidence given by the province of Alberta which showed that average field prices over the past five years have only increased $1.77 \mathrm{C}$ per mcf or roughly $13 \%$ compared with the $17 \%$ rise in the overall consumer index. This was true despite a rise in exports from $362 \mathrm{Bcf}$ to $608 \mathrm{Bcf}$ per year.

Banff Oil Ltd. expressed concern as to the need for exploration incentive. The company pointed out that 75 TCF were discovered in Western Canada "in the face of a depressed price incentive" and that a rising price structure should improve the finding rate. Banff further stressed that over-regulation would dull incentive, with the result that industry "will not find gas reserves anywhere approaching Canada's potential".

Dome Petroleum Ltd., took a similar stand. They contended that, as a general policy, export sales should be encouraged with a "minimum restraint" on pricing. Despite possible short-term increases, the company declared that such a policy would be in Canada's best long- 
term interest. Dome stated that Canada's vast reserve potential, coupled with a strong U.S. demand and indigenous supply shortage, offers Canada the opportunity of "reaping enormous benefits from these additional sales".

Dome observed that access to large U.S. markets and "a rapid load buildup will be necessary in order to justify the high cost of large scale facilities" necessary to tap the "great potential" of the Canadian Arctic. Dome further stressed that:

If the price of gas is artificially restrained, this might very well have the effect of rendering gas uneconomic which would have been economic had a competitively established price been available. This creates the economic waste of a valuable publicly-owned resource.

Amoco Canada Petroleum Company Ltd. expressed disapproval of Trans-Canada's intervention in Consolidated's application and stated that they find it "very difficult to understand the pessimism which pervades Trans-Canada's approach to the future reserves to be found in Canada". Amoco Canada also declared that there was no "competition in the real sense" before Consolidated's entry which has had a "healthy and buoyant effect on the gas industry in Western Canada". Amoco Canada also pointed out that as the search for new supply extends to more remote areas, high transportation costs require the producer "to accept a lower wellhead price and therefore the size of the reserves that have to be found have to be much greater in magnitude". Amoco Canada stated that producer incentive is the best way to ensure that "potential reserves become marketable reserves".

Canadian Fina Oil Limited urged the N.E.B. not to directly or indirectly regulate field prices. The company stated that competitive price of alternative fuels or energy sources should determine market penetration.

Amerada Hess Corporation intervened in support of Consolidated's application and also endorsed the C.P.A.'s gas reserve calculation. Amerada warned that Alberta gas might become "a less viable and less exciting proposition than it is at the present time" because of rapidly advancing technology and/or transportation procedures, as well as the development of gas supplies in other areas of Canada closer to market. Amerada stated that field price increases would have a "minimal effect on eastern consumer prices" which would be "quickly absorbed by economies of scale as consumption rises" and that price increases will assure a "continuing application of exploration and development funds to keep future needs and future discoveries in adequate balance".

\section{CONCLUSION}

Might we conclude with a modest forecast starting with a reminder that the National Energy Board does not have the power, in its own discretion, either to issue a certificate for a pipe line or to licence the export of gas. The pertinent provisions of the Act and the regulations are as follows:

44. The Board may, subject to the approval of the Governor in Council, issue a certificate in respect of a pipeline....

82. Subject to the regulations, the Board may issue licences, upon such terms and conditions as are prescribed by the regulations,

(a) for the exportation of power or gas.... 
8. (National Energy Board Part VI Regulations). All licences for the exportation of gas or power or the importation of gas shall be subject to the approval of the Governor in Council, and no such licence shall take effect until so approved.

In the light of these provisions and having in mind the current public debate about continental energy policies, total energy packages, oil exports, economic nationalism and so on, obviously, the decision on the applications for pipe line construction and for gas export will be a political one. We hasten to add that in saying this we don't intend to condemn the decison in advance without even knowing what it is. However, we do say that the decision will be based in large part upon a balancing of domestic and international political factors and that the real factors influencing the decision will never become public knowledge.

We also predict the gradual growth of the Board and its staff into the Canadian equivalent of the U.S. Federal Power Commission. There are those who would support such a development and those who would oppose it. We refrain from doing either. 